\title{
Seasonal changes in microbial biomass in the first-year ice of the Terre Adélie area (Antarctica)
}

\author{
Daniel Delille $^{1, *}$, Michel Fiala ${ }^{1}$, Jorma Kuparinen ${ }^{2}$, Harri Kuosa ${ }^{2}$, Charles Plessis ${ }^{1}$ \\ ${ }^{1}$ Observatoire Océanologique, Université P. et M. Curie, UMR-CNRS 7621, 66651 Banyuls-sur-mer cedex, France \\ ${ }^{2}$ Finnish Institute of Marine Research, POB 33, 00931 Helsinki, Finland
}

\begin{abstract}
The coastal sea ice in the vicinity of Dumont d'Urville station, Antarctica $\left(66^{\circ} 40^{\prime} \mathrm{S}\right.$, $140^{\circ} 01^{\prime} \mathrm{E}$ ) supports a diverse microbial community. To investigate seasonal changes in bacterial, microalgal and protozoan biomass during the ice-coverage period, a survey was conducted on fast ice in the continental shelf of Terre Adélie. A reference station was sampled twice a month from April to December 1997. In April and May, during sea ice formation, the autotrophic biomass reached relatively high levels ranging from 400 to $800 \mathrm{mg} \mathrm{C} \mathrm{m}^{-3}$ in the subsurface ice. A second increase reaching $1500 \mathrm{mg} \mathrm{C} \mathrm{m}^{-3}$ in mid-December occurred in early summer in the bottom ice layer. Bacterial biomass ranged from $<10 \mathrm{mg} \mathrm{C} \mathrm{m}^{-3}$ in August and September to $>200 \mathrm{mg} \mathrm{C} \mathrm{m}^{-3}$ in May. Maximal levels of bacterial biomass were detected during ice formation and just before the summer thaw. Total protozoan biomass increased from May to July. Maximum protozoan biomass $\left(31.8 \mathrm{mg} \mathrm{C} \mathrm{m}^{-3}\right)$ occurred in the surface ice layer in July. Except for during a short period (late May to early June), ciliates were dominant, accounting for 50 to $77 \%$ of the total protozoan biomass. During the ice-covered period, phototrophic biomass was always dominant. Microalgal biomass contributed on average $80.6 \%$ of total biomass whereas bacterial and protozoan biomass accounted for only 16.4 and $3 \%$, respectively. Despite their low biomass, protozoa seem to play a major role in bacterial regulation.
\end{abstract}

KEY WORDS: Antarctica $\cdot$ Sea ice $\cdot$ Protozoa $\cdot$ Bacteria $\cdot$ Ice algae

Resale or republication not permitted without written consent of the publisher

\section{INTRODUCTION}

One of the key factors influencing the Southern Ocean ecosystem is the annual advance and retreat of sea ice. The extent of sea ice ranges with seasons from $5 \times 10^{6}$ to $20 \times 10^{6} \mathrm{~km}^{2}$ (Maykut 1985). This large area of consistent ice coverage plays a key role in atmosphere-ocean interactions and global climate variability by way of both physical and biological processes.

Ice assemblages, like their pelagic counterparts, are hosts to a thriving microbial food web known as the sympagic biota and consist of a wide range of taxa, from bacteria to metazoans (Horner et al. 1992, Palmisano \& Garrison 1993, Ackley \& Sullivan 1994, Helmke \& Weyland 1995). The upper ice is usually a

*E-mail: delille@arago.obs-banyuls.fr colder, higher irradiated environment than the base of the ice (Stoecker et al. 2000). However, sea ice microbes successfully inhabit the surface, interior and bottom of the ice (Horner 1985, Archer et al. 1996). Sea ice algae are estimated to contribute 20 to $24 \%$ of the total primary production in the Southern Ocean (Knox 1990, Legendre et al. 1992, Kirst \& Wiencke 1995).

Bacterivory is generally considered the root of a system of trophic links that transports carbon up the food chain (Azam et al. 1983, Rassoulzadegan \& Sheldon 1986, Sherr et al. 1989, Christaki et al. 1998). The microbial loop can thus be a substantial subsidy to upper trophic levels, recovering carbon that would otherwise be lost from the system. Several short-time studies of the standing stocks of all major components of the microbial food web, e.g. algae, bacteria, flagellates and ciliates in sea ice, are available (Palmisano \& Sullivan 1983, Smith et al. 1995). In contrast, relatively few studies have investigated the long-term changes 
in microbial Antarctic sea ice communities (Watanabe \& Satoh 1987, Watanabe et al. 1990, Archer et al. 1996), and these studies were generally restricted to spring and summer.

Estimates of ratios of primary production to community respiration suggest that many parts of the ocean margins are net heterotrophic (Smith \& Mackenzie 1987). Several investigations have reported that during certain periods the microbial food web was the dominant pathway for carbon and energy flow in Antarctic seawater (James et al. 1996, Becquevort et al. 2000). During these periods bacterial biomass dominated phytoplankton carbon (Delille et al. 1995, Hall et al. 1999, Safi \& Hall 1999). In contrast, a study of Antarctic sea ice by Archer et al. (1996) demonstrated that during the spring period bacterial biomass contributed only 4 to $16 \%$ of the total microbial biomass in both interior and bottom ice. The aim of the present study was to describe the seasonal changes in the vertical distribution of microbial biomass and to evaluate the relative proportion of the 3 major compartments of the microbial loop for a 9 mo period in Antarctic first-year land-fast ice. of up to $300 \%$ more cells than the direct air-melting method (Garrison \& Buck 1986, Sime-Ngando et al. 1997). Following melting in the dark at $4^{\circ} \mathrm{C}$ for $\sim 24 \mathrm{~h}$, fixatives were added to specific subsamples. Bacterial samples were preserved with particle-free formaldehyde (4\% final concentration). Protozoan samples were preserved with $1 \%$ acid Lugol's iodine solution.

Melt samples were filtered through Whatman GF/F glass fibre filters under low vacuum ( $<5 \mathrm{~mm} \mathrm{Hg}$ ). Chlorophyll a (chl a) and phaeophytin a (phaeo a) were extracted with $90 \%$ acetone and their concentrations measured using a Perkin Elmer MPF 66 spectrofluorometer (Neveux \& Panouse 1987). The biomass of ice algae was estimated from chlorophyll concentrations assuming an average C:chl a ratio of 35, similar to that reported by Satoh \& Watanabe (1986) for bottom ice algae.

Bacteria were enumerated by epifluorescence microscopy (Hobbie et al. 1977). Acridine orange direct counts (AODC) were performed using an Olympus BHA microscope with acridine orange staining onto a $0.2 \mu \mathrm{m}$ pore size black Nuclepore filter. A minimum of 500 fluorescing cells with a clear outline and definite

\section{MATERIALS AND METHODS}

The study was conducted between early April and late December 1997 in the Géologie Archipelago (Terre Adélie, $\left.66^{\circ} 40^{\prime} \mathrm{S}, 140^{\circ} 01^{\prime} \mathrm{E}\right)$. The location of the sampling station was chosen for its accessibility throughout all the seasons. It was located $500 \mathrm{~m}$ offshore in the middle of a channel between the main islands of the archipelago $(20 \mathrm{~m}$ depth, Fig. 1). Ice samples were collected twice a month in a homogeneous and solid layer of fast ice using $10 \mathrm{~cm}$ (internal diameter) ice-coring augers. Core horizons were cut vertically into $20 \mathrm{~cm}$ segments with a sterile blade.

To avoid contamination from the ice auger, subsamples were taken from the centre of these segments, weighed and stored in a cool sterile glass box prior to melting. Subsamples were melted in a known volume of sterile artificial seawater composed of $30 \mathrm{~g} \mathrm{l}^{-1}$ $\mathrm{NaCl}$ dissolved in filtered distilled water. This was used as a salinity buffer to extract the ice communities. This dilution technique reduced osmotic shock and cell loss, and allowed the recovery

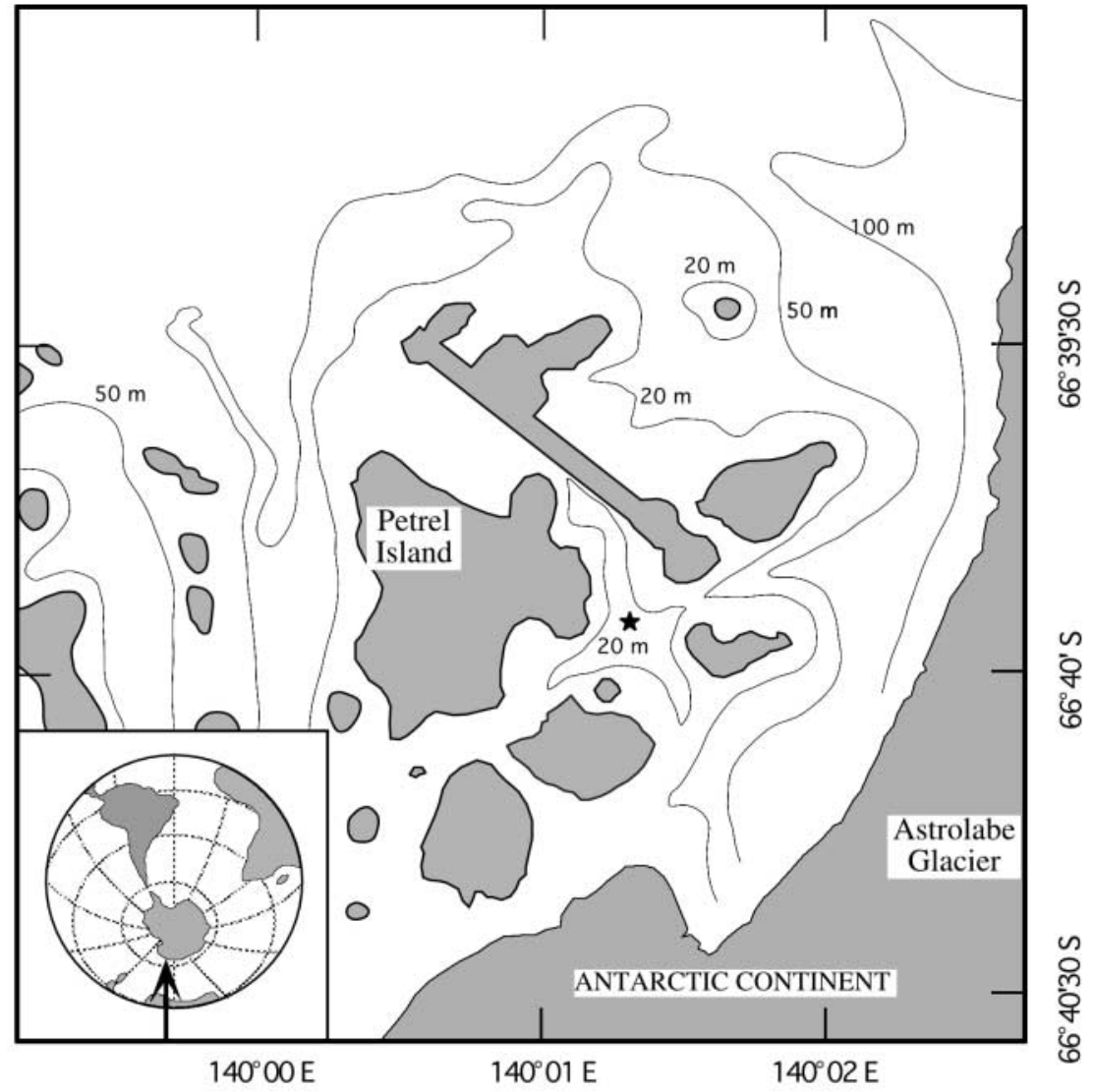

Fig. 1. The 'Pointe Géologie' Archipelago (Terre Adélie, Antarctica) with the location of the study station $(\star)$ 
cell shape were counted under oil immersion $(1000 \times)$ in a minimum of 10 randomly chosen fields. Biovolumes were estimated using an ocular micrometer. Bacterial biomass was calculated using 2 different methods: first, an average bacterial cell mass of $60 \mathrm{fg} \mathrm{C} \mathrm{cell}^{-1}$ (Bjørnsen 1986, Trousselier et al. 1997) was applied to total cell numbers and, secondly, a volume-specific

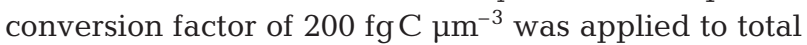
bacterial biovolume (Bjørnsen \& Kuparinen 1991, Archer et al. 1996, Theil-Nielsen \& Søndergaard 1998).

Protozoa were identified and enumerated with inverted microscopy (Utermöhl 1958). Subsamples (50 ml) were allowed to settle for $24 \mathrm{~h}$, and the whole counting cell was examined using a Leitz Diavert microscope with $25 \times$ and $40 \times$ objectives and phase contrast illumination. This technique is suitable for the enumeration of ciliates, dinoflagellates and
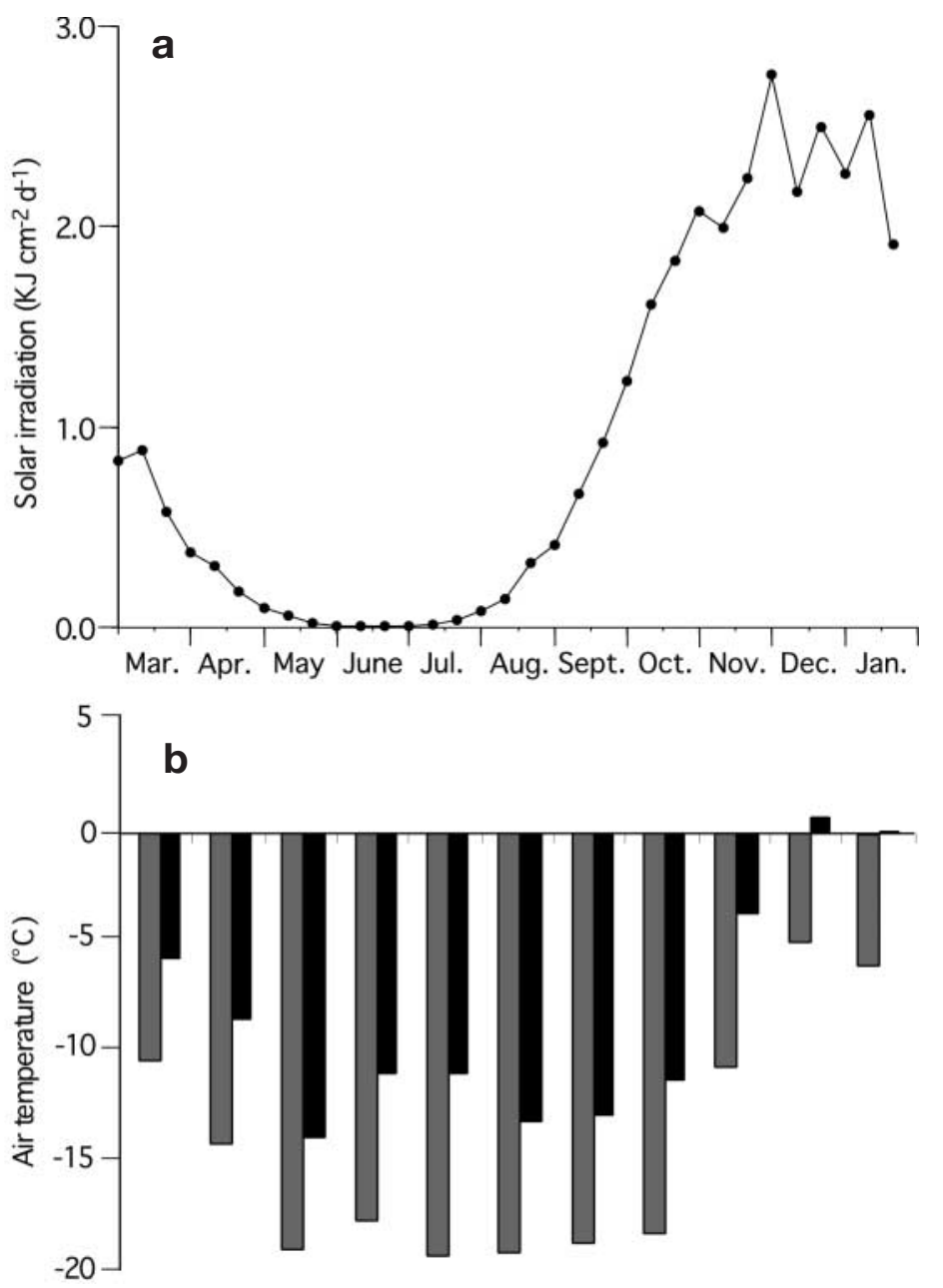

Fig. 2. (a) Seasonal changes in global solar irradiation $\left(\mathrm{kJ} \mathrm{cm}^{-2} \mathrm{~d}^{-1}\right)$ recorded at Dumont d'Urville station (Terre Adélie); (b) monthly mean values of minimum (grey) and maximum (black) air temperatures euglenophytes, but small $(<10 \mu \mathrm{m})$ heterotrophic flagellates cannot be differentiated from autotrophs. Thus, the latter could not be identified and are not included in the heterotrophic compartment in the present data set. Heterotrophic dinoflagellates were separated from plasticid cells by the absence of chloroplasts. All naked ciliates and dinoflagellates were counted in size classes with $10 \mu \mathrm{m}$ intervals. For biomass estimates the average cell volume of each size class was estimated by taking specimen-specific cell measurements of length and width of about 20 specimens from each size class and calculating cell volumes by commonly used geometrical formulae. Cell width was estimated from the known shape of the specimen. Volumes were converted to organic carbon from wet weight by assuming an $11 \%$ carbon content (Edler 1979). 


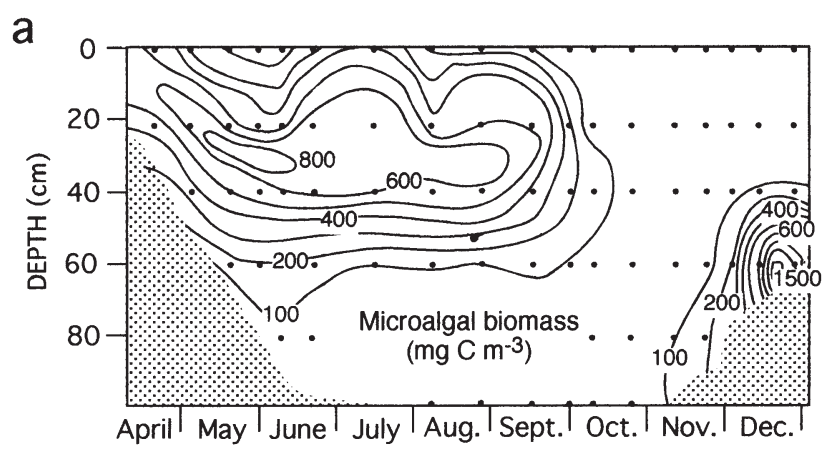

b

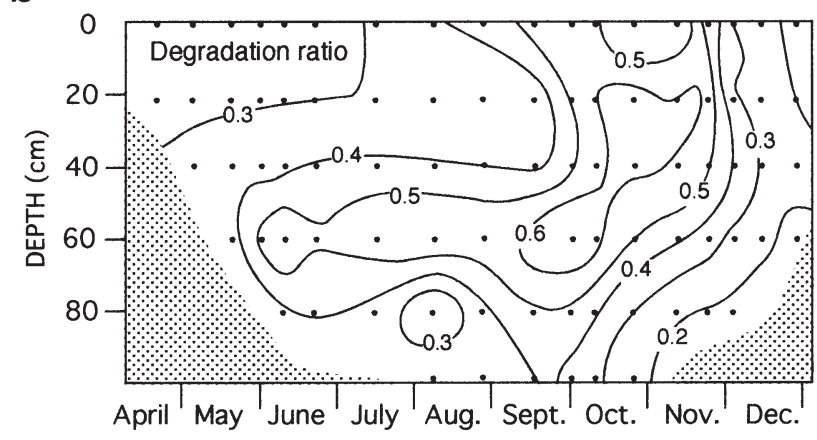

Fig. 3. Seasonal variation in distribution of (a) microalgal biomass and (b) degradation ratio (phaeophytin (phaeo) a/ chlorophyll (chl) $a+$ phaeo a) in sea ice from April to December 1997

phaeo a]) showed an inverse pattern to the algal biomass distribution (Fig. 3b). The latter was found to be low (0.2 to 0.3 ) during the algal development period from May to August in the surface layer and in November and December in the bottom ice. In contrast, the degradation ratio was highest (0.5 to 0.6 ) from May to September near the ice bottom and in September and October in the surface layer.

The general patterns of bacterial biomass distribution obtained by the 2 methods of estimation (conversion of bacterial abundance or bacterial biovolume) are quite similar (Fig. 4). A large increase of bacterial biomass occurred at the beginning of sea ice formation. Maximal values close to $200 \mathrm{mg} \mathrm{C} \mathrm{m}^{-3}$ were reached in May and June in the ice subsurface; thereafter, a regular decrease occurred until October. After winter minima $\left(<10 \mathrm{mgC} \mathrm{m}^{-3}\right)$, an increase was recorded in December at the bottom of the sea ice (60 to $100 \mathrm{mgC}$ $\mathrm{m}^{-3)}$. The mean bacterial cell volume showed the same trend of seasonal variations (Fig. 4b) with minimal values of $0.08 \mu^{3}$ in July in bottom ice and maximal values of $0.52 \mu^{3}$ in May in surface ice.

Throughout the sampling period, maximum protozoan biomass was located in the upper $40 \mathrm{~cm}$ of sea ice with abundance ranging from $1.4 \times 10^{3}$ to $60 \times 10^{3}$ cells l $^{-1}$ (data not shown). Total protozoan biomass increased a

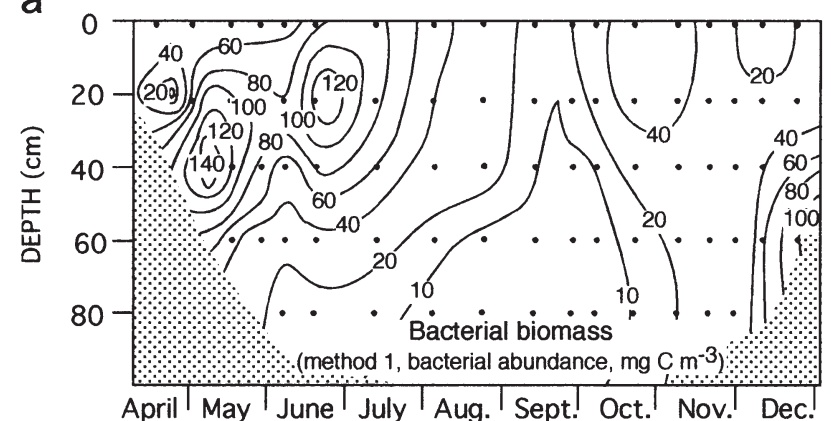

b

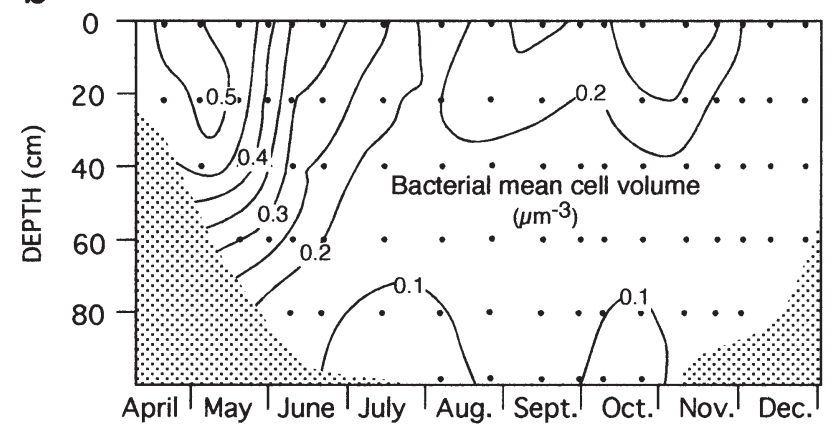

C

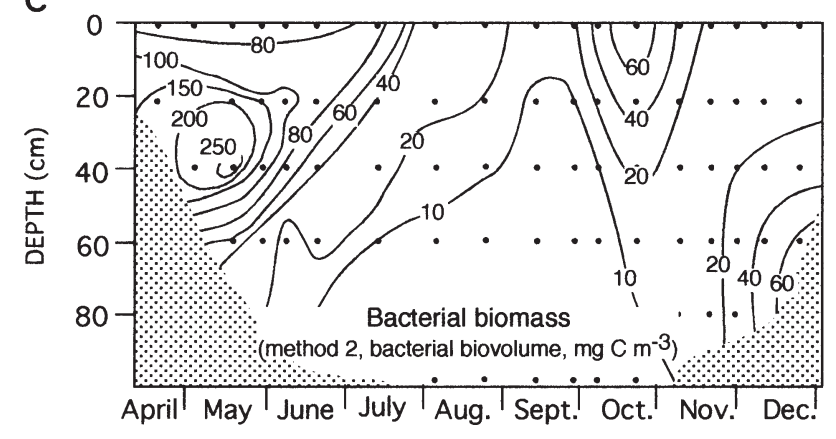

Fig. 4. Seasonal variation in distribution of total bacterial biomass estimated by conversion of (a) bacterial abundance or (c) bacterial biovolume and (b) bacterial mean cell volume in sea ice from April to December 1997

from May to July. The highest value $\left(31.8 \mathrm{mg} \mathrm{C} \mathrm{m}^{-3}\right)$ was recorded in June in the surface layer (Fig. 5a). A second moderate increase occurred in November (maximum $13.9 \mathrm{mg} \mathrm{C} \mathrm{m}^{-3}$ ) in the upper $20 \mathrm{~cm}$. During June and July biomass of ciliates and heterotrophic dinoflagellates in surface sea ice varied from 6 to $20 \mathrm{mgC} \mathrm{m}^{-3}$ and 4 to $15 \mathrm{mgC} \mathrm{m}^{-3}$, respectively (Fig. $5 \mathrm{~b}, \mathrm{c}$ ). The protozoan assemblage was mainly dominated by small flagellates and ciliates (10 to $100 \mu \mathrm{m}$, average $\sim 30$ to $40 \mu \mathrm{m})$. The ciliate biomass was integrated throughout the ice and accounted for 50 to $77 \%$ of the total protozoan biomass (Fig. 6a). The heterotrophic dinoflagellate biomass accounted on average for $34 \%$ of total protozoan biomass. Protoperidinium sp. cells were present but never important. 

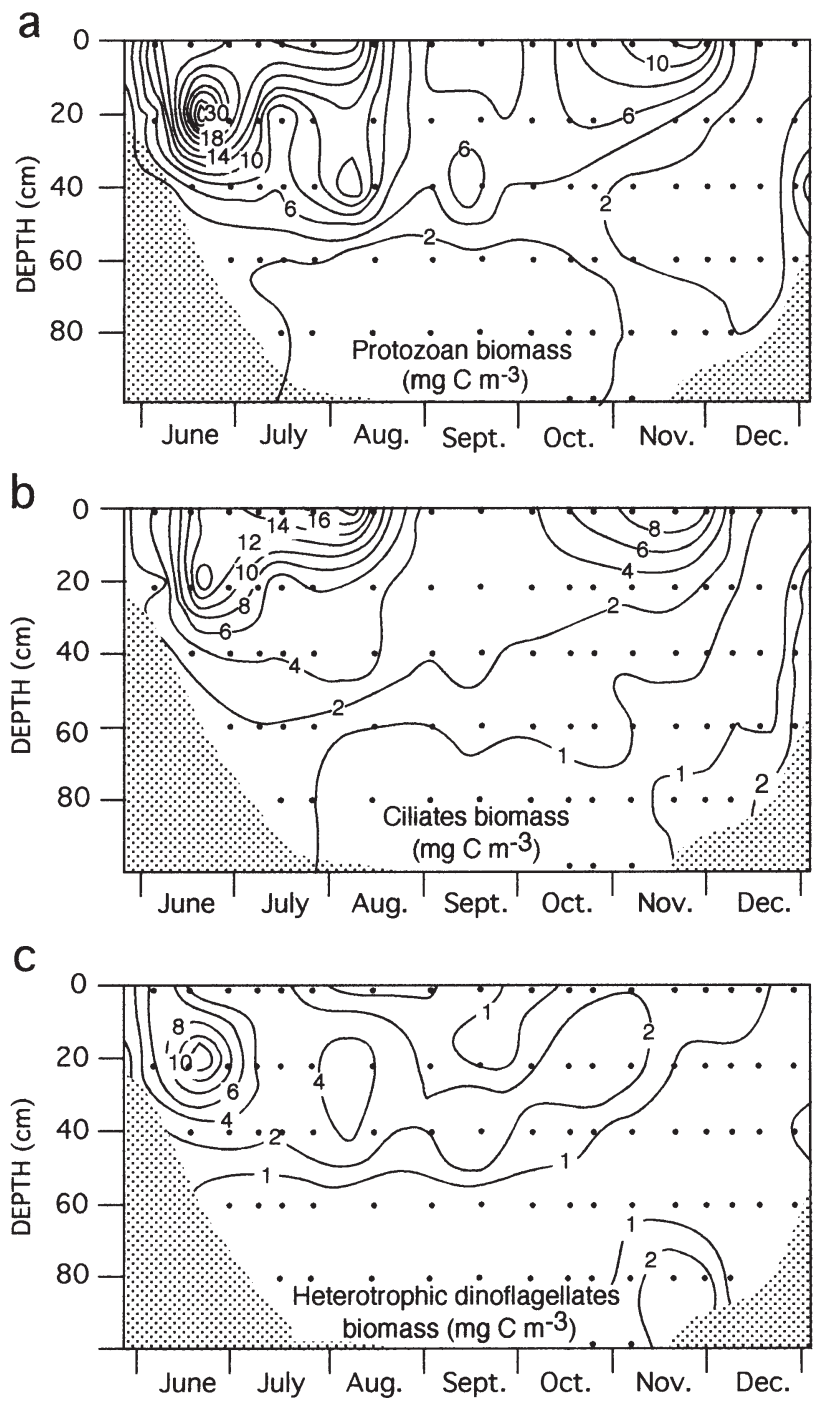

Fig. 5. Seasonal variation in distribution of (a) total protozoan biomass, (b) ciliate biomass and (c) heterotrophic dinoflagellate biomass in sea ice from late May to December 1997

Different tintinnid ciliates (Codonellopsis, Cymatocylis and Laackmanniella spp.) were also present; however, the bulk of ciliate biomass consisted of naked cells. Large quantities of differently sized Strombidium, Strobilidium and Holophrya type spp. were encountered. Adult copepods were absent in the ice cores, but some copepod nauplii were found in the bottom of sea ice from May to November (data not shown). Nevertheless, their biomass was always low, ranging from 1 to $28 \mathrm{mgC} \mathrm{m}^{-3}$.

Throughout the ice-covered period, algae appear to dominate the living biomass. Algal biomass accounted for more than $80 \%$ of total C biomass (Fig. 6b), except during early summer (50 to $72 \%$ in October and November). Bacterial biomass contributed 8 to $20 \%$ of total C biomass but reached more than $25 \%$ in October and November (maximum $45.3 \%$ ). The contribution of protozoan biomass was low, representing on average $3 \%$ of total microbial biomass (minimum $0.1 \%$, maximum $16.1 \%$ ).

\section{DISCUSSION}

It is difficult to establish a universal C:chl $a$ ratio in sea ice. The C:chl a ratio changes with light availability, temperature, nutrient concentrations and microalgae species (Cloern et al. 1995, Geider et al. 1997). Garrison \& Buck (1991) reported a C:chl a ratio ranging from 14 to 270 for the surface layer of sea ice. In this study we applied an average C:chl a ratio of 35 for the entire ice thickness, this mean value being close to those reported by Satoh \& Watanabe (1986) for bottom ice microalgae. Using this conversion factor, the general seasonal distribution of algal biomass in the whole ice column corresponds excellently with the observations of Fiala \& Delille (1999) in the same station and to those of Günther \& Dieckmann (1999) in the Weddell Sea. In ice-covered regions, most of the algal biomass in land-fast ice is usually concentrated in the bottom few centimetres of the ice sheet (Cota \& Smith 1991). However, rich microalgal assemblages can develop at the surface of sea ice within areas of submerged ice that are infiltrated with seawater (Ackley et al. 1979). Indeed, microalgal biomass can reach levels considerably greater than those found in the underlying seawater (Fiala \& Delille 1992, Delille et al. 1995). However, in this study the maximal autotrophic biomass

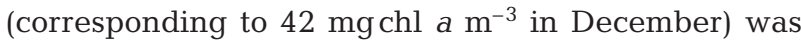
low relative to relevant published data. In platelet ice, the maximum chl a concentration is usually less than $200 \mathrm{mg} \mathrm{m}^{-3}$ (Günther \& Dieckmann 1999), but seasonal chl a maxima ranging from 600 to $2900 \mathrm{mg} \mathrm{m}^{-3}$ have been reported in the bottom layer of land-fast ice (Palmisano \& Sullivan 1983, Watanabe et al. 1990).

In the Southern Ocean, Gleitz et al. (1994) have reported the development of near shore open water algal blooms in late summer. The remainder of these algal blooms are incorporated into the newly formed sea ice during the pancake ice cycle (Gleitz \& Thomas 1993). On the other hand, Watanabe et al. (1990) observed an algal bloom at the bottom ice near Syowa Station in autumn. This bottom assemblage was enclosed by new ice formation, thus becoming an internal community. As our study began in late April, we found the remains of only one, or both, of these autumnal processes. During winter months irradiation was very low, which leads to light limitation and low light adaptation of ice algae, and consequently the microalgal assemblage is degraded progressively and its 
a

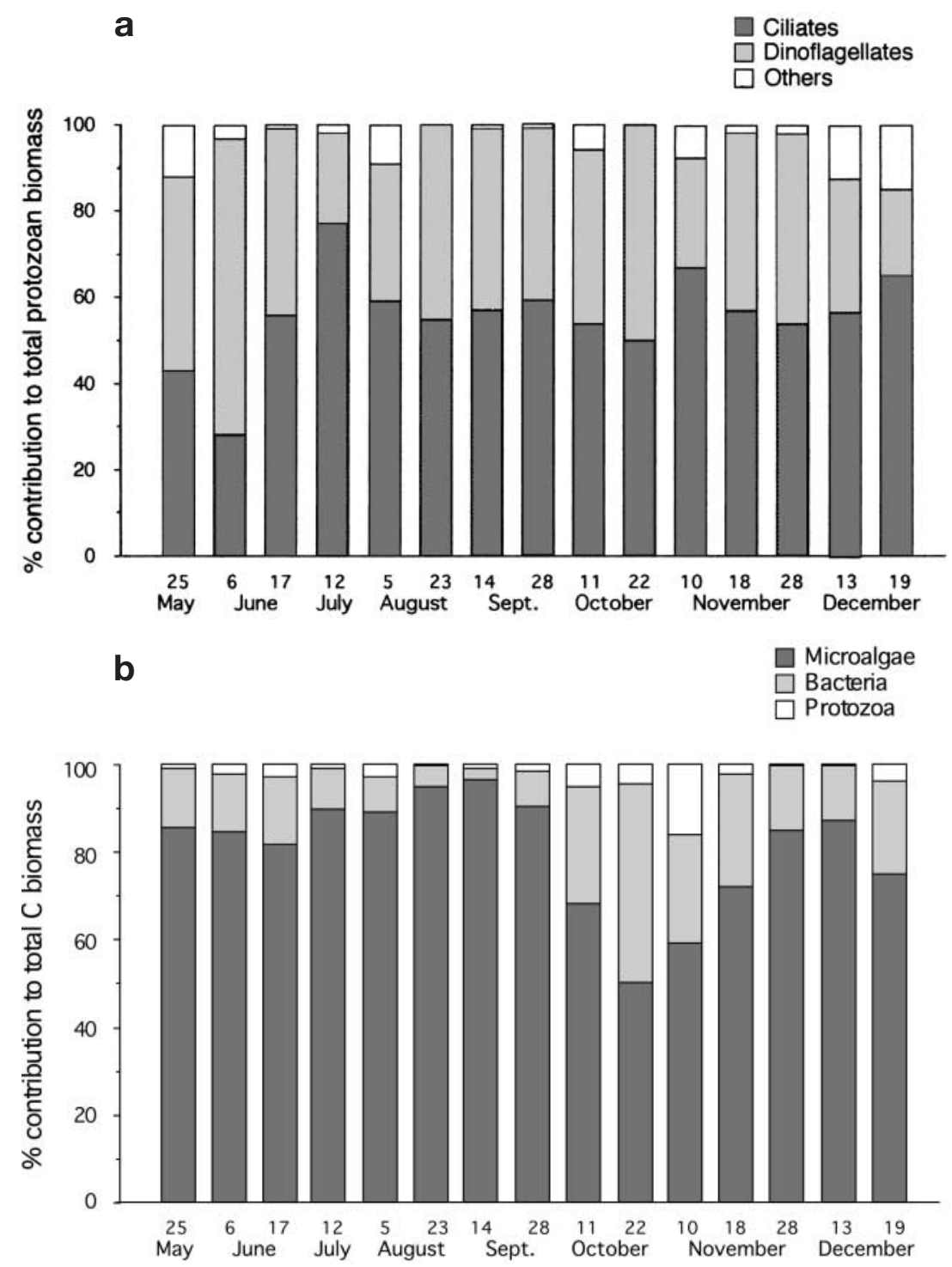

Fig. 6. (a) Relative contribution (\%) of ciliates and dinoflagellates to the total integrated protozoan biomass; (b) relative contribution (\%) of microalgae, bacteria and protozoa to the total integrated biomass bacterial growth conditions, it is not surprising to observe a wide spectrum of conversion factors. One of the most commonly used factors for biovolume conversion is

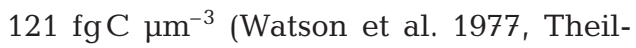
Nielsen \& Søndergaard 1998). However, in the Southern Ocean, Bjørnsen \& Kuparinen (1991) found a conversion factor of $400 \mathrm{fg} \mathrm{C}$ $\mu^{-3}$. Considering all these available data, the extreme values for the biovolume conversion factor would be in the range of

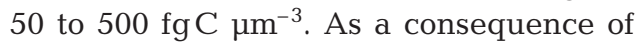
the low correlation between carbon per cell and cell volume, a constant cell mass seems to be a logical choice for bacterial biomass estimation (Berger et al. 1995, Trousselier et al. 1997). Cell mass is, however, also subject to controversy. If, for some specific species, cell mass is quite constant during cell-volume decreases associated with starvation (Trousselier et al. 1997), then for an assemblage of different species, cell mass would remain dependent on cell volume (Gazol et al. 1995, Pernthaler et al. 1996, Theil-Nielsen \& Søndergaard 1998). Considering all available observations, the extreme values of bacterial cell mass would be in the range of 20 to $120 \mathrm{fg} \mathrm{C} \mathrm{cell}^{-1}$. Using

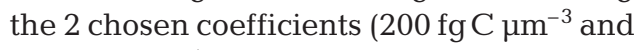
$60 \mathrm{fgC} \mathrm{cell}^{-1}$ ), the 2 calculation modes of bacterial biomass give rather similar results, which are consistent with the data previously reported for the same area (Delille et al. 1995).

Good correlation between bacterial and primary production has been reported in sea ice (Archer et al. 1996, Haecky \& Andersson 1999). It is thus not surprising that bacterial biomass paralleled algal biomass in the present study. However, the pathways that mediate the transfer of nutrients biomass decreases. At the onset of spring, a new bottom sea ice assemblage becomes established, contributing to the second biomass increase observed in November and December. In the Weddell Sea, platelet layer algae have been reported to account for more than $99 \%$ of total fast ice biomass (Günther \& Dieckmann 1999). Such platelet layers may congeal to sea ice and form a part of the late spring bottom sea ice assemblage.

In studies of carbon dynamics in aquatic microbial communities, the ability to convert bacterial abundance or bacterial biovolume to carbon is crucial in order to calculate bacterial biomass. Considering variability due to differences in bacterial species composition and between the primary producers and bacteria are extremely complex and include numerous feedback mechanisms (Thingstad et al. 1999). Heterotrophic bacteria are largely reliant on phytoplankton for their energy supply, either directly through excretion of dissolved organic matter (Suttle et al. 1991) or indirectly after decomposition of dead phytoplankton cells (Riemann \& Sondergaard 1986). On the other hand, it is generally assumed that most of the primary production in pelagic ecosystems is sustained by a continuous and rapid recycling of the growth-limiting inorganic nutrients (Azam et al. 1983, Berman et al. 1987). Depending on the food web structure, bacteria may be either a link in food webs supporting metazoan production or 
largely a sink where bacterial production is respired by microorganisms (Wylie \& Currie 1991, Vaqué et al. 1992). Microalgae may be physically enriched within newly forming sea ice by the 'scavenging' effects of frazil ice crystals (Garrison et al. 1989). Enrichment of bacterial cells in new ice occurred in conjunction with ice algae cells (Grossmann \& Dieckmann 1994). Such phenomena could partly explain the bacterial peak observed in the fall. In this study the proportion of bacterial carbon in the total microbial biomass increased from $<3 \%$ in September to $>45 \%$ in October. As previously reported (Garrison \& Close 1993), algae appear to dominate the living sympagic biomass. However, drastic seasonal changes could occur.

The large bacterial densities in sea ice provide an abundant food source for the bacterivorous protozoan. Although alternative sources of bacterial loss are likely to be of importance, evidence for the potential of protozoan assemblages as bacterial grazers in sea ice has been provided (Archer et al. 1996). An observed peak in bacterial abundances induced clear increases of protozoan biomass (June to July and November). On the other hand, protozoan herbivory is increasingly recognised as a significant pathway in the marine food web (Bjørnsen \& Kuparinen 1991, Burkill et al. 1995, Klaas 1997). Ice algae assemblages are generally dominated by large pennate diatoms (Levasseur et al. 1995, Guglielmo et al. 2000, Riaux-Gobin et al. 2000), and there are reports that phagotrophic protozoa and ciliates can ingest such large diatoms (Smetacek 1981, Suttle et al. 1986). In Antarctic sea ice, pennate diatoms were the most common item in the food vacuoles of a flagellate of $50 \mu \mathrm{m}$ size (Buck et al. 1990). The major peak of protozoan biomass (June and July) followed a concomitant increase of microalgae and bacterial biomass. However, it is interesting to note that bacterial biomass decreased dramatically after maximum protozoan counts were reached, while in contrast, protozoan development had no visible effect on phototrophic biomass. These observations suggest that bacteria are a major food source for protozoa in the studied sea ice.

As previously reported in the Southern Ocean (Bjørnsen \& Kuparinen 1991, Becquevort 1997, Becquevort et al. 2000) heterotrophic dinoflagellates generally dominate the protozoan assemblage. Small oligotrich ciliates most probably feed by filtering small particles (Stabell 1997) and based on oral ciliature structure they may grow on an exclusive diet of bacteria (Sherr et al. 1989). The maximum number of ciliates $\left(9 \times 10^{6}\right.$ cells m$\left.^{-3}\right)$ could consume about 2 to $4 \%$ of bacterial biomass per day if the measured values of Stabell (1997) are used. This corresponds to a maximal ingestion rate of 200 to 400 bacteria ciliate ${ }^{-1} \mathrm{~h}^{-1}$ or to total community ingestion of about $40 \times 10^{9}$ to $80 \times 10^{9}$ bacteria $\mathrm{m}^{-3} \mathrm{~d}^{-1}$. The calculated ingestion rates fit with the rates measured by Hadas et al. (1998), but they also show that there is a wide variability, depending on species, in ciliate grazing on bacteria. Thus, we need more information on ciliate communities in order to estimate bacterial grazing by ice-related ciliates. Though the daily clearance is only a small percentage of the maximum bacterial abundance, it may be enough to control slow growing bacterial communities and affect bacterial size structure. The results suggest ciliate control of bacterial size, i.e. selective bacterial grazing, as high ciliate abundance correlated with decreasing bacterial cell size. However, in the present study, protozoan biomass represents only a small part of their potential prey biomass.

Bearing in mind the various assumptions involved and the use of generalised conversion factors, it appears that, in contrast with several observations reported for the Southern Ocean waters (Delille et al. 1995, Becquevort et al. 2000), phototrophic biomass is dominant in sea ice. Microalgal biomass contributed on average $80.6 \%$ of total biomass, whereas bacterial biomass accounted for $16.4 \%$. Even using the extreme conversion factors available in the literature, bacterial biomass cannot exceed $50 \%$ of the microbial biomass. Although protozoa accounted for only $3 \%$ of the total biomass, it seems that they can play a major role in bacterial regulation.

Acknowledgements. This research was supported by the French Polar Institute (IFRTP) and CNRS (UMR 7621). We express our sincere thanks to our colleague T. Collins for help in improving the English and to anonymous referees for useful comments.

\section{LITERATURE CITED}

Ackley SF, Sullivan CW (1994) Physical controls on the development and characteristics of Antarctic sea ice biological communities - a review and synthesis. Deep-Sea Res 41: 1583-1604

Ackley SF, Buck K, Tagushi S (1979) Standing crop of algae in the sea ice of the Weddell Sea region. Deep-Sea Res 26: $269-281$

Archer SD, Leakey RJG, Burkill PH, Sleigh MA, Appleby CJ (1996) Microbial ecology of sea ice at a coastal Antarctic site: community composition, biomass and temporal change. Mar Ecol Prog Ser 135:179-185

Azam F, Fenchel T, Field JG, Gray JSS, Meyer-Reil LA, Thingstad F (1983) The ecological role of water-column microbes in the sea. Science 203:451-453

Becquevort S (1997) Nanoprotozooplankton of the Atlantic section of the Southern Ocean in early spring biomass and feeding activities. Deep-Sea Res 44:335-374

Becquevort S, Menon P, Lancelot C (2000) Differences of the protozoan biomass and grazing during spring and summer in the Indian sector of the Southern Ocean. Polar Biol 23: 309-320

Berger B, Hoch B, Kavka G, Herndl GJ (1995) Bacterial 
metabolism in the River Danube. Freshw Biol 34:601-616

Berman T, Nawrocki M, Taylor GT, Karl DM (1987) Nutrient flux between bacteria, bacterivorous nanoplanktonic protists and algae. Mar Microb Food Webs 2:69-82

Bjørnsen PK (1986) Automatic determination of bacterioplankton biomass by image analysis. Appl Environ Microbiol 51:1199-1204

Bjørnsen PK, Kuparinen J (1991) Growth and herbivory by heterotrophic dinoflagellates in the Southern Ocean studied by microcosm experiments. Mar Biol 109:397-405

Buck KR, Bolt PA, Garrison DL (1990) Phagotrophy and fecal pellet production by an athecate dinoflagellate in Antarctic sea-ice. Mar Ecol Prog Ser 60:75-84

Burkill PH, Edwards ES, Sleigh MA (1995) Microzooplankton and their role in controlling phytoplankton growth in the marginal ice zone of the Bellingshausen Sea. Deep-Sea Res 42:1277-1290

Christaki U, Dolan JR, Pelegri S, Rassoulzadegan F (1998) Consumption of picoplankton-size particles by marine ciliates: effects of physiological state of the ciliate and particle quality. Limnol Oceanogr 43:458-464

Cloern JE, Grenz C, Vidergar-Lucas L (1995) An empirical model of the phytoplankton chlorophyll:carbon ratio: the conversion factor between productivity and growth rate. Limnol Oceanogr 40:1313-1321

Cota GF, Smith REH (1991) Ecology of bottom ice algae: II. Dynamics, distributions and productivity. J Mar Syst 2: 279-295

Delille D, Fiala M, Rosiers C (1995) Seasonal changes in phytoplankton and bacterioplankton distribution at the ice-water interface in the Antarctic neritic area. Mar Ecol Prog Ser 123:225-233

Edler L (1979) Recommendations on methods for marine biological studies. Balt Mar Biol Publ 5:1-38

Fiala M, Delille D (1992) Variability and interactions of phytoplankton and bacterioplankton in the Antarctic neritic area. Mar Ecol Prog Ser 89:135-146

Fiala M, Delille D (1999) Annual changes of microalgae biomass in Antarctic sea-ice contaminated by crude oil and diesel fuel. Polar Biol 21:391-396

Garrison DL, Buck KR (1986) Organism losses during ice melting: a serious bias in sea ice community studies. Polar Biol 10:211-219

Garrison DL, Buck KR (1991) Surface-layer sea ice assemblages in Antarctic pack ice during the austral spring: environmental conditions, primary production and community structure. Mar Ecol Prog Ser 75:161-172

Garrison DL, Close AR (1993) Winter ecology of the sea ice biota in Weddell Sea pack ice. Mar Ecol Prog Ser 96:17-31

Garrison DL, Close AR, Reimntz E (1989) Algae concentrated by frazil ice: evidence from laboratory and field measurements. Antarct Sci 1:313-316

Gazol JM, Del Giorgio P, Massana R, Duarte CM (1995) Active versus inactive bacteria: size-dependence in a coastal marine plankton community. Mar Ecol Prog Ser 128:91-97

Geider RJ, MacIntyre HL, Kana TM (1997) Dynamic model of phytoplankton growth and acclimatation responses of the balanced growth rate and the chlorophyll a:carbon ratio to light, nutrient limitation and temperature. Mar Ecol Prog Ser 148:187-200

Gleitz M, Thomas DN (1993) Variation in phytoplankton standing stock, chemical composition and physiology during sea ice formation in the southeastern Weddell Sea, Antarctica. J Exp Mar Biol Ecol 173:211-230

Gleitz M, Bathmann UV, Lochte K (1994) Build-up and decline of summer phytoplankton biomass in the eastern
Weddell Sea, Antarctica. Polar Biol 14:413-422

Grossmann S, Dieckmann GS (1994) Bacterial standing stock, activity, and carbon production during formation and growth of sea ice in the Weddell Sea, Antarctica. Appl Environ Microbiol 60:2746-2753

Guglielmo L, Carrada GC, Catalano G, Dell'Anno A and 5 others (2000) Structural and functional properties of sympagic communities in the annual sea ice at Terra Nova Bay (Ross Sea, Antarctica). Polar Biol 23:137-146

Günther S, Dieckmann GS (1999) Seasonal development of algal biomass in snow-covered fast ice and the underlying platelet layer in the Weddell Sea, Antarctica. Antarct Sci 11:305-315

Hadas O, Malinsky-Rushansky N, Pinkas R, Cappenberg TE (1998) Grazing on autotrophic and heterotrophic picoplankton by ciliates isolated from Lake Kinneret, Israel. J Plankton Res 20:1435-1448

Haecky P, Andersson A (1999) Primary and bacterial production in sea ice in the northern Baltic Sea. Aquat Microb Ecol 20:107-118

Hall JA, James MR, Bradford-Grieve JM (1999) Structure and dynamics of the pelagic microbial food web of the subtropical convergence region east of New Zealand. Aquat Microb Ecol 20:95-105

Helmke E, Weyland H (1995) Bacteria in sea ice and underlying water of the eastern Weddell Sea in midwinter. Mar Ecol Prog Ser 117:269-287

Hobbie JE, Daley RJ, Jasper S (1977) Use of nuclepore filters for counting bacteria by fluorescence microscopy. Appl Environ Microbiol 33:1225-1228

Horner R (1985) Sea ice biota. CRC Press, Boca Raton, FL

Horner R, Ackley SF, Dieckmann GS, Gulliksen B and 6 others (1992) Ecology of sea ice biota 1. Habitat, terminology, and methodology. Polar Biol 12:417-427

James MR, Hall JA, Barret DP (1996) Grazing by protozoa in marine coastal and oceanic ecosystems off New Zealand. NZ J Mar Freshw Res 30:313-324

Kirst GO, Wiencke C (1995) Ecophysiology of polar algae. J Phycol 31:181-189

Klaas C (1997) Microprotozooplankton distributions and grazing impact in the Antarctic Circumpolar Current. DeepSea Res 44:375-394

Knox GA (1990) Primary production and consumption in McMurdo Sound, Antarctica. In: Kerry KR, Hempel G (eds) Antarctic ecosystems. Ecological change and conservation. Springer-Verlag, Berlin, p 115-128

Legendre L, Ackley SF, Dieckmann GS, Gulliksen B and 6 others (1992) Ecology of sea ice biota. 2. Global significance. Polar Biol 12:429-444

Levasseur M, Gosselin M, Michaud S (1995) A new source of dimethylsulfide (DMS) for the arctic atmosphere: ice diatoms. Mar Biol 121:381-388

Maykut GA (1985) The ice environment. In: Horner R (ed) Sea ice biota. CRC Press, Baca Raton, FL, p 21-82

Neveux J, Panouse M (1987) Spectrofluorometric determination of chlorophylls and pheophytins. Arch Hydrobiol 109: 567-581

Palmisano AC, Garrison DL (1993) Microorganisms in Antarctic sea ice. In: Friedmann EI (ed) Antarctic microbiology. Wiley-Liss, New York, p 167-218

Palmisano AC, Sullivan CW (1983) Sea ice microbial communities (SIMCO) I. Distribution, abundance and primary production of ice microalgae in McMurdo Sound, Antarctica in 1980. Polar Biol 2:171-177

Pernthaler J, Sattler B, Simek K, Schwarzenbacher A, Psenner R (1996) Top-down effects on the size-biomass distribution of a freshwater bacterioplankton community. Aquat 
Microb Ecol 10:255-263

Rassoulzadegan F, Sheldon RW (1986) Predator-prey interactions of nanozooplankton and bacteria in an oligotrophic marine environment. Limnol Oceanogr 31:1010-1021

Riaux-Gobin C, Tréguer P, Poulin M, Vétion G (2000) Nutrients, algal biomass and communities in land-fast ice and seawater off Adélie Land (Antarctica). Antarct Sci 12: $160-171$

Riemann B, Sondergaard GA (1986) Regulation of bacterial secondary production in two eutrophic lakes and in experimental enclosures. J Plankton Res 8:519-536

Safi KA, Hall JA (1999) Mixotrophic and heterotrophic nanoflagellate grazing in the convergence zone east of New Zealand. Aquat Microb Ecol 20:83-93

Satoh H, Watanabe K (1986) Photosynthetic nature of icealgae under fast ice near Syowa Station, Antarctica. Mem Natl Inst Polar Res, Spec Issue 44:34-42

Sherr FB, Sherr EB, Pedros-Alio C (1989) Simultaneous measurement of bacterioplankton production and protozoan bacterivory in estuarine water. Mar Ecol Prog Ser 54: 209-219

Sime-Ngando T, Juniper SK, Demers S (1997) Ice-brine planktonic microheterotrophs from Saropma-ko Lagoon, Hokkaido (Japan): quantitative importance and trophodynamics. J Mar Syst 11:149-161

Smetacek V (1981) The annual cycle of protozooplankton in the Kiel Bay. Mar Biol 63:1-11

Smith REH, Demers S, Hattori H, Kudoh S and 9 others (1995) Biological and chemical investigations of the Saroma-Resolute project in ice-covered Resolute Passage, 1992. Can Data Rep Hydrogr Ocean Sci 137

Smith SV, Mackenzie FT (1987) The ocean as a net heterotrophic system: implication from the carbon biogeochemical cycle. Global Biogeochem Cycles 1:187-198

Stabell T (1997) Ciliate bacterivory in epilimnetic waters. Aquat Microb Ecol 10:265-272

Stoecker DK, Gustafson DE, Baier CT, Black MMD (2000) Primary production in the upper sea ice. Aquat Microb Ecol 21:275-287

Editorial responsibility: David Caron,

Los Angeles, California, USA
Suttle CA, Chan AM, Taylor WD, Harrison PJ (1986) Grazing of planktonic diatoms by microflagellates. J Plankton Res 8:393-398

Suttle CA, Chan AM, Fuhrman JA (1991) Dissolved free amino acids in the Sargasso Sea: uptake and respiration rates, turnover times, and concentrations. Mar Ecol Prog Ser 70:189-199

Theil-Nielsen J, Søndergaard M (1998) Bacterial carbon biomass calculated from biovolumes. Arch Hydrobiol 141: 195-207

Thingstad TF, Pérez M, Pelegri S, Dolan J, Rassoulzadegan F (1999) Trophic control of bacterial growth in microcosms containing a natural community from northwest Mediterranean surface waters. Aquat Microb Ecol 18: 145-156

Trousselier M, Bouvy M, Courties C, Dupuy C (1997) Variation of carbon content among bacterial species under starvation condition. Aquat Microb Ecol 13:113-119

Utermöhl H (1958) Zur Vervollkommnung der quantitativen Phytoplankton-Methodik. Mitt Int Ver Theor Angew Limnol 9:1-38

Vaqué D, Pace ML, Findlay S, Lints D (1992) Fate of bacterial production in a heterotrophic ecosystem: grazing by protists and metazoans in the Hudson Estuary. Mar Ecol Prog Ser 89:155-163

Watanabe K, Satoh H (1987) Seasonal variations of ice algal standing crop near Syowa Station, East Antarctica, in 1983/84. Bull Plankton Soc Jpn 34:143-164

Watanabe K, Satoh H, Hoshiai T (1990) Seasonal variation in ice algal assemblages in the fast ice near Syowa Station in 1983/84. In: Kerry KR, Hempel G (eds) Antarctic ecosystems. Ecological change and conservation. SpringerVerlag, Berlin, p 136-142

Watson SW, Novitsky TJ, Quinby HL, Valois FW (1977) Determination of bacterial number and biomass in the marine environment. Appl Environ Microbiol 33:940-946

Wylie JL, Currie DJ (1991) The relative importance of bacteria and algae as food sources for crustacean zooplankton. Limnol Oceanogr 36:708-729

Submitted: August 3, 2001; Accepted: April 15, 2002

Proofs received from author(s): June 27, 2002 